\title{
EDUKASI PERAWATAN GENETALIA PADA WANITA USIA SUBUR DI POSYANDU PRINGSEWU BARAT
}

\author{
Cynthia Puspariny \\ Universitas Muhammadiyah Pringsewu (UMPRI), Lampung, Indonesia \\ e-mail: cynthiabrv85@gmail.com
}

\begin{abstract}
Genetalia hyegiene or genitals personal hygiene is a treatment that includes the genital hygiene that you perform yourself. This activity provides genitalia care education that focuses on maintaining the genital $\mathrm{pH}$ of women of childbearing potential to increase mothers' motivation and ability to perform daily gene care at home. This Activity aims at the mother who come to Posyandu to weigh their babies in the west of Pringsewu Posyandu with a total of 42 participants. The learning method used is providing theories and exercise that show how to deal with genitals. Many participants were thrilled to ask questions, $90 \%$ of the participants had a better understanding of how to properly care for genes. Development of other methods that can help fully educate genitals care and strengthen the role of the husband as a form of family support in maintaining reproductive health so that the mothers' motivation to care for genitals can be increased.
\end{abstract}

Keywords-Education, genitals treatment, women of childbearing age.

\section{PENDAHULUAN}

Definisi kesehatan reproduksi telah diatur dalam Undang-Undang RI Nomor 36 Tahun 2009 tentang Kesehatan, yaitu merupakan keadaan sehat secara fisik, mental dan sosial secara utuh, tidak semata-mata bebas dari penyakit atau kecacatan yang berkaitan dengan sistem, fungsi, dan proses reproduksi pada lakilaki dan perempuan. Salah satu organ tubuh yang paling penting dan sensitif serta memerlukan perawatan khusus adalah sistem reproduksi. Penerapan pelayanan kesehatan reproduksi oleh Departemen Kesehatan RI dilaksanakan secara integratif memprioritaskan pada empat komponen kesehatan reproduksi yang menjadi masalah pokok di Indonesia. Salah satu gangguan klinis dari infeksi atau keadaan abnormal alat kelamin adalah keputihan (Direktorat Kesehatan Keluarga, 2017).

Menurut survey demografi kasus keputihan 200 kasus, tetapi hanya sekitar 95 kasus yang mengalami gejala keputihan dengan rasa gatal. Masalah keputihan ini sering kali tidak diperhatikan oleh wanita yang menderita penyakit ini, akan tetapi masalah keputihan ini jika tidak segera ditangani akan menyebabkan masalah yang serius (DepKes RI, 2010).Kejadian infeksi pada alat kelamin luar, bisa disebabkan oleh karena menurun-nya $\mathrm{pH}$ keasaman vagina, serta terbunuhnya flora normal 
pada vagina, yang mana berfungsi sebagai pembunuh kuman/ bakteri patogen /bakteri penyebab penyakit yang masuk ke vagina, anus/cebok setelah buang air besar bagi wanita perlu diperhatikan kesehatannya (Mandriwati1, G.A dan Padmiyani, N.K, 2013).

Terjadinya gangguan kesehatan reproduksi seperti keputihan, infeksi saluran kemih (ISK), Penyakit radang panggul (PRP) dan kemungkinan terjadi kanker leher rahim, sehingga dibutuhkan informasi yang baik mengenai kesehatan reproduksi agar wanita memiliki pemahaman yang baik dan dapat mencegah ancaman penyakit reproduksi merupakan akibat dari kurangnya pemahaman perawatan genetalia (Mita, 2015).

Kebersihan genitalia atau personal hygiene genitalia merupakan perawatan yang meliputi kebersihan genitalia yang dilakukan diri sendiri. Kebiasaan menjaga kebersihan, termasuk kebersihan organ seksual atau reproduksi merupakan awal dari usaha menjaga kebersihan. kebersihan organ reproduksi harus lebih dijaga karena kuman mudah sekali masuk dan dapat menimbulkan peyakit pada saluran reproduksi. Maka pengabdian masyarakat kali ini yaitu memberikan edukasi perawatan genetalia pada wanita usia subur (WUS) dan memberikan produk sabun perawatan vagina sesuai $\mathrm{pH}$.

\section{METODE}

Edukasi yang diberikan berupa cara perawatan genetalia yang menitikberatkan pada pemeliharaan $\mathrm{pH}$ Genetalia Wanita Usia Subur sehingga meningkatkan motivasi dan keterampilan ibu dalam melakukan perawatan genetalia sehari-hari di rumah. Sasaran pada kegiatan pengabdian masyarakat ini adalah ibu - ibu yang datang ke posyandu untuk menimbang bayinya di posyandu Pringsewu Barat yang hadir berjumlah 42 peserta. Metode pembelajaran yang digunakan adalah ceramah tanya jawab dan praktik dengan demontrasi cara perawatan genetalia agar memberikan pengetahuan dasar mengenai perawatan genetalia.

Langkah pertama dengan tanya jawab dan diskusi dengan wanita usia subur yang hadir ke posyandu Matahari namun dikarenakan kehadiran tidak bersamaan maka pemberian materi dan Tanya jawab di bagi 2 sesi. Pada langkah ini diharapkan pengabdi dapat memperoleh apersepsi, pemahaman awal tentang perawatan genetalia dan memberikan penjelasan mengenai perawatan genetalia secara luas sehingga peserta dapat mengimplentasikan apa yang di peroleh dalam kegiatan sehari- hari yang berhubungan dengan perawatan genetalia.

Langkah selanjutnya adalah demonstrasi, metode ini dilakukan untuk menjelaskan cara perawatan genetalia dari perawatan saat menstruasi, penggunaan celana dalam, hingga cara membersihkan genetalia dan perawatan genetalia apa saja yang dilakukan saat sebelum dan sesudah BAK dan BAB. Demonstrasi ini dilakukan dengan pamflet perawatan Genetalia, sehingga mempermudah ibu-ibu mengingat kembali saat di rumah. Setelah itu peserta memperoleh sabun untuk membersihkan genetalia dengan $\mathrm{pH}$ yang sesuai. 
Untuk mengetahui seberapa besar keberhasilan kegiatan pengabdian masyarakat ini dapat dilihat dari antusias peserta dalam mengikuti kegiatan. Pemberian edukasi ini juga menggunakan angket untuk menilai tingkat kepuasan peserta terhadap kegiatan pengabdian masyarakat. Lalu pengabdi memberikan sabun perawatan vagina sesuai $\mathrm{pH}$ vagina agar dapat digunakan di rumah.

\section{HASIL DAN PEMBAHASAN}

Perawatan genetalia merupakan cara menjaga kebersihan diri dan menjaga kesehatan agar terhindar dari infeksi. Untuk itu perlu dilakukan perawatan alat reproduksi secara teratur seperti melakukan pembersihan dengan air dan melakukan cebok yang benar yaitu dari arah depan ke belakang. Dalam perawatan genetalia dianjurkan untuk membilas dan menggosok bagian vagina dengan cermat, terutama setelah buang air kecil. Hal ini dimaksudkan untuk mencegah tertinggalnya sisa air kemih ataupun kotoran lainnya. Setelah itu keringkan vagina dengan menggunakan tisu ataupun handuk kecil (Pribakti, 2012).

Banyaknya penelitian menyatakan rendahnya tingkat pengetahuan mengenai perawatan kebersihan genitalia eksternal seperti penelitian yang dilakukan oleh Congol juga melaporkan frekuensi infeksi genitalia lebih besar (38.1\%) pada mereka yang membersihkan area genitalia dengan salah dan sekitar $(35,1 \%)$ pada mereka yang membersihkan area genitalia dengan benar (Sevil et al, 2013). Maka memberikan edukasi tentang cara perawatan genetalia pada wanita usia subur dapat mengurangi resiko terjadinya infeksi genetalia.

Kebiasaan sehat menggunakan celana dalam untuk wanita adalah; bahan dari katun/kaos yang mudah mengisap keringat, dipakai dalam kondisi bebas kuman dengan menyeterika setelah mencuci, jika tidak memungkinkan untuk menyeterika pada saat mencuci jemur di tempat yang aman dari paparan kuman, dan diganti setiap kotor. Kebiasaan yang tidak sehat menggunakan celana dalam untuk wanita yaitu bahan celana dalam tidak menyerap keringat, akibatnya di sekitar kemaluan menjadi lembab, gatal-gatal dan lecet, sehingga kuman mudah berkembangbiak. Celana dalam yang dipakai terkontaminasi kuman karena tidak segera diganti bila sudah kotor, atau waktu mencuci dijemur di tempat yang terkontaminasi kuman, tidak diseterika sebelum menggunakannya, dan ukuran celana dalam terlalu sempit (ketat).

Untuk menghindarkan terkontaminasinya alat kelamin dari kotoran setelah buang air besar perlu membersihkan kotoran yang masih menempel di anus menggunakan sabun dan air bersih. Pada saat membersihkan tangan menghapus sisa/bekas kotoran kearah belakang sedemikian rupa, sehingga tidak menyentuh alat kelamin. Sabun dan cairan antiseptik saat ini banyak digunakan oleh para wanita dari kalangan remaja, dewasa sampai ibu-ibu rumah tangga dalam membersihkan alat kelamin. Pemilihan sabun yang tepat dengan kandungan $\mathrm{pH}$ yang sesuai dengan $\mathrm{pH}$ alami genetalia dimana genetalia memiliki $\mathrm{pH}$ yang asam, yakni sekitar 3,5 - 4,5. Tingkat keasaman ini memungkinkan vagina untuk memelihara bakteri baik. Jadi tidak diperlukan penggunaan sabun khusus pembersih vagina. 
Tujuan dari kegiatan pemberian edukasi tentang perawatan genetalia pada wanita usia subur ini agar wanita usia subur dapat melakukan perawatan vagina dengan benar. Pemahaman cara merawat genetalia dapat diterapkan pada kehidupan wanita usia subur sehari-hari sehingga dapat memberikan rasa nyaman dan meningkatkan rasa percaya diri seorang wanita. Hal tersebut tentu berdampak pada peningkatan kualitas hidup wanita dalam kesehatan reproduksi.
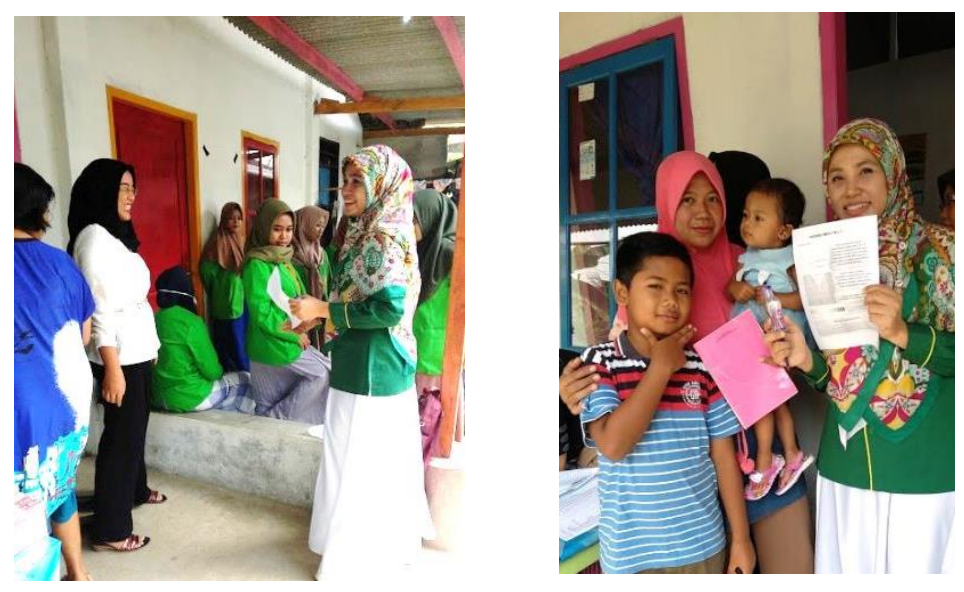

Gambar 1 Foto Kegiatan

Hasil dari kegiatan ini dari 42 peserta 90\% mengalami peningkatan pemahaman mengenai cara perawatan genetalia yang benar. Hal itu terbukti dari hasil evaluasi dimana sebagian besar dapat mengulang dengan benar mengenai materi dan praktik cara perawatan genetalia. Dalam melakukan diskusi pun banyak peserta yang antusias mengajukan pertanyaan. Pertanyaan yang diajukan pun cukup bervariasi dari perawatan genetalia pasca persalinan hingga perawatan yang tepat setelah berhubungan seksual.

Namun masih terdapat $10 \%$ dari peserta, masih kurang pemahamannya atau belum dapat dilakukan evaluasi berdasarkan hasil pengkajian. Beberapa dari mereka beralasan tidak memiliki waktu yang cukup untuk mendengarkan penjelasan dan terburu-buru setelah mendapatkan pelayanan posyandu, terdapat juga yang kurang fokus memperhatikan penjelasan karena mereka membawa balita yang rewel saat dilakukan kegiatan tersebut. Hal tersebut berhubungan kurangnya motivasi sebagian kecil dari wanita usia subur yang datang ke posyandu tersebut untuk mengikuti kegiatan ini. Seperti dikemukakan (Hamzah, 2012; dalam Puspariny, 2019) motivasi adalah dorongan dasar yang menggerakan seseorang bertingkah laku. Motivasi juga dapat dikatakan sebagai perbedaan antara dapat melaksanakan atau mau melaksanakan atau motivasi juga dapat diartikan sebagai proses untuk mencoba mempengaruhi orang atau orang-orang yang dipimpinnya agar melakukan pekerjaan yang diinginkan. Sehingga motivasi dalam memahami pentingnya memelihara kesehatan reproduksi perlu ditingkatkan dan upaya tersebut merupakan bagian dari peran bidan dan tenaga kesehatan lainnya dalam 
memberikan edukasi yang tepat tidak hanya pada ibu saja namun meliputi seluruh anggota keluarga terutama dukungan dari suami guna meningkatkan motivasi ibu.

\section{KESIMPULAN}

Kegiatan Edukasi Perawatan Genetalia WUS ini berbentuk laporan hasil berupa peningkatan pengetahuan ibu dan bertambahnya pemahaman ibu dalam melakukan perawatan genetalia. Keberhasilan ini dapat dilihat dari:

1. Terdapat beberapa pertanyaan dalam proses kegiatan diskusi

2. Adanya respon yang positif terhadap kegiatan ini

3. Mengalami Kenaikan pemahaman tentang perawatan Genetalia hingga $90 \%$

\section{SARAN}

Kegiatan pengabdian masyarakat ini tentunya banyak kekurangan yang dapat dibenahi dengan pengabdian lanjutan, sehingga adanya metode lain yang dapat membantu semakin maksimal untuk para peserta dalam melakukan edukasi tentang Perawatan Genetalia dan peningkatan peran suami sebagai bentuk dukungan keluarga dalam memelihara kesehatan reproduksi sehingga motivasi ibu dalam melakukan perawatan genetalia dapat meningkat.

\section{UCAPAN TERIMA KASIH}

Kegiatan edukasi masyarakat ini berjalan dengan lancar karena beberapa pihak yang membantu dalam kegiatan ini. Penulis mengucapkan terimakasih kepada:

1. Universitas Muhammadiyah Pringsewu Lampung

2. Puskesmas Rejosari

3. Segenap Civitas Akademika

4. Dukungan keluarga.

\section{DAFTAR PUSTAKA}

Departemen Kesehatan RI. 2010. Kesehatan Remaja Problem dan Solusinya. Jakarta: Sinar Harapan.

Direktorat Kesehatan Keluarga (2017). Upaya Pemenuhan Hak Kesehatan Reproduksi Melalui Pelayanan Kesehatan Reproduksi Terpadu (PKRT).

Mandriwati1, G.A dan Padmiyani, N.K. (2013) Kebiasaan Memelihara Kebersihan Alat Kelamin pada Pasien Abortus di RSUP Sanglah Denpasar Tahun 2013 Jurnal Kesehatan Reproduksi Vol. 4 No 3, Desember: 141 - 151 
Mita, Anggun \& dkk. (2015). Hubungan Perawatan Genetalia dengan Kejadian Keputihan pada Santriwati Pondok Pesantren Aliman Sumowono Kabupaten Semarang. http:// perpusnwu.web.id (Diakses Desember 2019, pukul 20: 00 wib).

Pribakti, B. (2012). Tips dan Trik Merawat Organ Intim. Jakarta: Sagung Seto pp. $1017,30-32$.

Puspariny, Cynthia (2019). Korelasi Pengetahuan dan Motivasi dengan Keaktifan Kader Posyandu Di Wilayah Kerja Puskesmas Wates Kabupaten Pringsewu Lampung. Jurnal Kebidanan EMBRIO vol 11 (No. 2), Desember: 72 - 79

Sevil et al. (2013). An Evaluation of the Relationship Between Genital Hygiene Pratices, Genital Infection. Gynecology and Obstetrics. 3(6) 